Nagy, Dorottya. "Displaying Diaspora: Chinese Christian Presence in Hungary after 1989.” AHEA: E-journal of the American Hungarian Educators Association, Volume 5 (2012): http://ahea.net/e-journal/volume-5-2012

\title{
Displaying Diaspora: Chinese Christian Presence in Hungary after 1989
}

Dorottya Nagy, Central and Eastern European Institute for Mission Studies, Budapest

\begin{abstract}
The present article draws attention to the significance of the "Christian" component in researching Chinese migrants' presence in post-1989 Hungary within the framework of Chinese globalization and the globalization of Chinese Christianity. After a brief review of the dynamics of Chinese migration to Hungary and special focus on the formation of Chinese Christian Communities, the article examines how the concept of diaspora and the rhetoric built around it is used by missionaries to create new ways of understanding the world from migrants' perspective and interpreting migration experiences as empowering and liberating divine arrangements for the well-being of their current residence and beyond. The case of Chinese migration to Hungary shows that the concept of diaspora implies a diverse range of community formation practices and the complexity of negotiating Chineseness, which highlights the need of revisiting the very concept of diaspora as reduced to a homogeneous and ethnically essentialized community.
\end{abstract}

Keywords: Chinese migration to Hungary, Chinese Christianity, diaspora discourses

Biography: Dorottya Nagy is a Senior Lecturer and Program Coordinator of the Master of Theology in Missiology Program at the Central and Eastern European Institute for Mission Studies, Budapest. After completing her PhD at Utrecht University in 2008 with her thesis titled Migration and Theology: The Case of Chinese Christian Communities in Hungary and Romania in the Globalisation-Context, she worked as a post-doctoral research fellow at the Max Planck Institute for the Study of Religious and Ethnic Diversity in Göttingen, Germany. Her research interests include theological conceptualizations of migration phenomena, contextual theology, missionary networks, and Christianity in post-communist settings. She is an ordained minister of the Evangelical Lutheran Church in Hungary.

The case of Chinese migration to Central and Eastern Europe (CEE), and to Hungary in particular, is a scholarly example of how quickly certain populations respond to local and global political and economic changes, and how such responses create unprecedented patterns of mobility affecting socio-political, economical, religious and geographic developments. Prior to the political changes of the late eighties, there was no Chinese presence in CEE except for a small number of Chinese exchange students and diplomats. However, around 1989, political events in CEE and the People's Republic of China (PRC) prepared the soil for Chinese migration to Hungary $(\mathrm{CMH})$. After the collapse of the Soviet Union, regardless of entrepreneurial background, Chinese migrants managed to make their way through the chaos of undeveloped migration policies to Russia, Ukraine, Hungary, Poland, Czechoslovakia, Yugoslavia, Bulgaria and Romania, and all of a sudden, all countries in the CEE block, including the Balkans, were targeted by Chinese migration, also starting a new type of chain migration to Western Europe and thereby justifying the conceptualization of Chinese migration in terms of a trade diaspora (Cohen 1998).

The complex (hi)story of CMH characterized by the multidirectional, linear and circular mobility of a regionally, religiously, socially, and educationally diverse group of migrants had contested the rigid model of emigration and immigration from its earliest days. Due to its nature and dynamics, from 1990 onwards Chinese migrants have become the 
Nagy, Dorottya. "Displaying Diaspora: Chinese Christian Presence in Hungary after 1989.” AHEA: E-journal of the American Hungarian Educators Association, Volume 5 (2012): http://ahea.net/e-journal/volume-5-2012

second largest group and certainly the most visible group of migrants to Hungary after Hungarian speaking migrants from neighboring countries. Although many aspects of $\mathrm{CMH}$ are well-documented (e.g. Nyíri 1997, 1999, 2001, 2003, 2005, 2006, 2010; Mészáros 1998; Polonyi 2008; Irimiás 2008), the present article draws on on-going fieldwork started in 2004 to revisit the issue of $\mathrm{CMH}$, focusing on Chinese Christian communities in which diaspora discourses continue to shape migrants' self-understanding and their understanding of migration. The present article seeks to avoid generalizations such as "the" Chinese community or "the Chinese diaspora" in Hungary due to the fact that Chinese migrants create multiple types of communities and/ or community-like associations (business, language, culture, charity and so on) that enhance networking and create a sense of belonging (Ma and Cartier 2003). Forming a community based on religious affiliation is one of the more effective ways of networking and nurturing both communal and individual belonging, and the present paper focuses on the community-forming role of Christianity through its agents, in particular the missionaries (another type of migrant) for Chinese migrants in Hungary, and on the role of diaspora discourses within the communities. However, before we can discuss these communities, it is worth noting that community formation itself was largely pre-conditioned by the patterns of $\mathrm{CMH}$.

By the 1990's, Chinese migrants identified the economic opportunities in Hungary and the neighboring post-Communist countries and sought to create a niche by establishing their own enterprises (Okólski and Grabowska-Lusińka 2009). Within a few years, CEE was interwoven with formal and informal Chinese trade networks, resulting in a more predictable geographic mobility of Chinese migrants. Some migrants started their business in Romania and then branched out to Peru or Italy through Hungary and Germany, conducting business in both countries as well as in Romania. However, there were also examples of Chinese entrepreneurs using those same networks not merely to conduct business but to actually migrate from Western Europe to CEE. For instance, one of the elders of a Chinese church in Budapest used to live in Belgium before he travelled back to China in order to get married and then settled down in Hungary. These examples demonstrate that $\mathrm{CMH}$ is not a unique case but belongs to the broader context of Chinese globalization (Pieke et al. 2004) viewed from the interconnected aspects of the development of China's emigration policy, with China becoming a major player within the global economic system and human mobility as a reaction to global socio-political changes.

The imperial and post-imperial Chinese state has always played a dominant role regarding issues of emigration and still continues to shape China's economic strategy on the international platform, adopting strict and prohibitive, and eventually, more open and even encouraging attitudes towards migration. There was a major shift in China's perception of migration and in the relation between the PRC and Chinese overseas when an "all-nation overseas conference" was held in Beijing in December 1977, where the Chinese Communist Party declared that all patriots inside and outside China are one family, meaning that Chinese overseas were expected to serve their motherland (Barabantseva 2005). After an explicit period of prohibited migration between 1949-1978, China revisited its stance on migration at the Third Plenum of the Eleventh Central Committee of the Chinese Communist Party. By opting for "socialist modernization", in December 1978 China began to open its economy and soon established economic contacts with the USA, which also implied the mobilization of Chinese overseas. This open policy culminated in China becoming a member of the World Trade Organization on December 11, 2001, after which the "Overseas Chinese" were treated as "a characteristic of China's unique national situation." In other words, the Chinese government considered Overseas Chinese as belonging to China and serving to "build a bridge of overseas connections (yi qiao da qiao)," thereby becoming a channel for "absorbing 
Nagy, Dorottya. "Displaying Diaspora: Chinese Christian Presence in Hungary after 1989.” AHEA: E-journal of the American Hungarian Educators Association, Volume 5 (2012): http://ahea.net/e-journal/volume-5-2012

manpower, intellect, and financial resources for the promotion of socialist modernization" (Nagy 2009: 86-87).

Chinese economic reforms beginning in the late seventies and culminating in the late eighties called for a double approach to migration focusing on both emigration and immigration. After the economic reforms in 1978, the Chinese government continued to export labor as a means of decreasing domestic unemployment. The Exit-Entry Control Law of 1986 (to be revoked by July 2013) contained special measures regarding the issuance of "service passports", favoring state employees intending to conduct business outside China. At first, the reformed policy was aimed at returning Overseas Chinese in order to benefit from their foreign know-how. However, this project was eventually expanded to all Chinese overseas, calling on them to invest in China. The establishment of Special Economic Zones and open cities in the Eastern coastal area of China are a good example of how top-down migration and economic development created new dynamics in society, politics, culture and religion. In the early nineties, China's migration policy was further loosened by extending the notion of Overseas Chinese to foreign Chinese overseas as well, thus regarding all ethnic Chinese living abroad as members of the same family (Mette 2001). This paradigm shift in PRC's migration policy introduced the term new (Chinese) migrants (xin yimin) and later the term Zhongguo de yimin (migrants from China) for citizens who left China after 1978, and while these terms do not cover a homogeneous group of people, they do accentuate the political interpretation and perception of PRC migrants abroad. According to PRC, however, the term "new Chinese migrants" implies homogeneity based on the assumption that migrants have a strong and stable identity by virtue of sharing the same racial and cultural background (Barabantseva 2005 quoting Guotu Zhang, 15).

China's post-1978 migration and economic policies, briefly outlined above, operate through nationalistic discourses where the idea that both PRC citizens and Chinese overseas belong to one great China expresses the government's politico-economical desire to develop, establish and maintain an emotional attachment to the motherland not only among those who emigrate, migrate or immigrate from PRC, but also among people who, through past migration trajectories, can potentially be labeled as Chinese. Such an emotional attachment can be maintained by flexible citizenship, in which case developments in technology and transportation allow frequent visits to the motherland. This way, the migrant experience perceives migration as an indefinite series of movements, where leaving and returning no longer seem definite. Of course, economic, intellectual, religious and political factors also play a significant role in the development of this emotional bind. The aim of the PRC is to bring together Overseas Chinese under the banner of patriotism and the idea of Chinese unity, and this aim is apparently viable on an organizational level. The PRC seems to enter the field of internationalism successfully through her overseas Chinese, claiming Central government leadership over them under the policy of "dual-anchoredness", which turns emigration from shameful disloyalty into a "patriotic and modern act" (see Nyíri 2001 building on Vertovec and Cohen 1999) and has contributed to the visibility of Chinese presence in Hungary and abroad in general. However, concrete case studies may contest the validity of unity achieved through governmental ideology.

The presence of New Chinese migrants in Hungary dates back to October 1988, when in the spirit of loyal friendship, ${ }^{1}$ the PRC and Hungary signed a bilateral agreement that allowed passport-holding citizens of both countries to enter each other's territory without any visa requirements. Cheap travel facilities offered by the Trans-Siberian Railroad also made

\footnotetext{
${ }^{1}$ Hungary, together with Romania, Bulgaria, and Czechoslovakia, was one of the first CEE countries that initiated diplomatic relations with the PRC on October 4, 1949, just three days after the proclamation of the PRC (Vámos 2006).
} 
Nagy, Dorottya. "Displaying Diaspora: Chinese Christian Presence in Hungary after 1989.” AHEA: E-journal of the American Hungarian Educators Association, Volume 5 (2012): http://ahea.net/e-journal/volume-5-2012

travelling to Hungary increasingly more attractive to financially secure and well-educated citizens of the PRC, and CMH from the PRC, first disguised as tourism, gradually started to boom. At first, CMH unfolded the way "tourism" used to be practiced within the Soviet Block, meaning that tourists always travelled with goods they could sell in order to acquire local currency, a phenomenon also known as "shuttle trade". This way, PRC migrants rapidly identified what goods were on demand in Hungary that were also easily transportable and brought high profit. This agreement also created an escape route for those involved in or frightened by the Tiananmen Square massacre, causing CMH from a multitude of localities within the PRC. Compared to cases of earlier PRC migration to Western Europe where migration was dominantly based on kinship networks and connecting the localities of emigration and immigration (chain migration), shuttle-trade tourism was relatively new and atypical.

The shuttle trade between the PRC and Hungary benefitted greatly from entering open-air markets (OAM), which provided easy access for the first PRC migrants into Hungarian social space. OAMs are the simplest form of trading activity done on the street or places designed for this purpose, and a legitimate means of distributing goods. They were places of exchange "in which the social, cultural, political and economic characteristics of the actors influence the extent and manifestation of the market principle, which is [...] present in all transactions" (Sík 1999: 698). OAMs brought together people of different ethnic (such as Chinese, Vietnamese, Arab, Russian, Gypsy, and Hungarian) and social groups, who might otherwise not interact with each other. OAMs, however, were also considered dangerous places and were closely linked to criminal activity. There is, undoubtedly, illegal CMH as well, but CMH should not be reduced to a single dimension of illegality and criminality when Chinese traders also experience OAMs as unsafe places, operating under the constant threat of a corrupt local police system and the presence of several criminal organizations. Perceptions of Chinese immigrants are also skewed by Hungarians associating them with places such as the Four Tiger Market, a commercial hub for Chinese entrepreneurs opened in 1994 in Budapest, which entered into the collective memory of Hungarians and foreigners alike as the only place where one could meet and interact with Chinese migrants. One may also presume that many of the xenophobic myths and images pertaining to Chinese migrants originate in the negative personal experiences with Chinese, seen as 'the Other'.

The socio-political changes in China and the bilateral visa-agreement between China and Hungary resulted in a "Hungary fever" in China, (Xiongyali re, Nyíri 1997: 53), maintained both through verbal communication in personal networks and through written official or quasi official propaganda. Providing plausible numerical data on Chinese migrants in Hungary is difficult, and estimates always differ between official statistics and local legends and myths about the Chinese population. By 1990 the official numbers on Chinese migrants entering and/or residing in Hungary increased from almost zero to nearly 12,000, and by the following year to some 27,000 , while non-official data recorded up to 50,000 Chinese migrants for the same period. By the time the visa- agreement of 1988 was cancelled in April 1992, there were about 1,500 Chinese-owned small and medium enterprises registered (Nyíri 2010), constituting a constant and significant Chinese presence in this migratory context. The importance and relevance of $\mathrm{CMH}$ does not depend on spectacular numbers, however, since the unfolding (hi)story of $\mathrm{CMH}$ is more about a small group of people forming part of a larger group of people (conceived in terms of Chinese globalization) who are connected to an even larger community which is being conceptualized in terms of its Chineseness, whatever that might imply. 
Nagy, Dorottya. "Displaying Diaspora: Chinese Christian Presence in Hungary after 1989.” AHEA: E-journal of the American Hungarian Educators Association, Volume 5 (2012): http://ahea.net/e-journal/volume-5-2012

From the beginning, $\mathrm{CMH}$ was characterized by a large number of higher educated migrants within the group, the diversity regarding places of origins in the PRC, young and middle-aged agents, and the relatively large number of female migrants taking up entrepreneurial roles. Unlike chain migrations known form earlier migration histories to Western Europe (receiving migrants from Fujian and Zhejiang provinces, for example), communities formed by regional affiliation are not as prevalent in $\mathrm{CMH}$. Conventional categorization divides the population of Chinese migrants in Hungary into a clear but nondominant group of Northeastern Fujian and Zhejiang migrants, largely considered less educated, and the so-called "Northern people", who are generally regarded to be more educated. In their case, geographical diversity leads to the de-homogenization of the nationalistic discourse described earlier, but also creates new intercultural discourses and levels of unity in Christian communities. Under the given circumstances of migration, the constellation of the four factors mentioned above lead from the very beginning to the conception of a self-conscious, self-determined and self-styled life ethos among migrants, which was sufficient to create a Chinese constant with Mandarin as its lingua franca in Hungary within a relatively short amount of time.

Although the reintroduction of strict visa restrictions in 1992 made a number of Chinese migrants leave Hungary, those who stayed and those who managed to travel to Hungary and establish themselves legally under the new immigration laws became more visible than before through membership in associations and through the Chinese media. For example, the Hungarian Chinese Association (HCA) was established in 1992 and eventually began to publish its own weekly newspaper, first published in 1994. The first issue discusses the mission of the association and mentions the organization of charity events and philanthropic activities for the benefit of Hungarians and local Chinese as well as for the PRC, the propagation of patriotism and one's obligations to the home country, the organization of services and cultural events for Chinese, the protection of Chinese interests in dealing with Hungarian authorities, Hungarian social networking, nurturing contacts with overseas Chinese organizations and informing the Chinese community (Nagy 2009: 102). During this period, numerous other organizations were established, such as the Organization of Chinese Writers in Hungary, the Association of Chinese Women in Hungary, and the first Chinese Christian Church.

Besides associations and communities, organizing the life of Chinese migrants in Hungary on the entrepreneurial level required several services offered by both Mandarinspeaking and Hungarian-speaking people. For example, they created a network of Hungarian lawyers specifically to safeguard the legality of Chinese businesses and residence, and most entrepreneurs consulted Hungarian bookkeepers and employed at least one Hungarianspeaking employee. Chinese families with child(ren) usually kept a babysitter as well. However, Chinese-speaking people and fellow Chinese migrants also responded to the needs of Chinese migrant entrepreneurs. A group of Chinese migrants set out to create an information and communication network among Chinese migrants themselves, local society, the PRC society and the envisioned worldwide Chinese community as well. At the beginning of the new millennium, there were nine Chinese newspapers published in Hungary, and these newspapers now created internet platforms and helped organize cultural and other social events. There was also a group of Chinese migrants, most of them coming from the saturated Chinese catering business of Western European countries, who sought to provide for the culinary needs of Chinese migrants and also establish a Chinese (fast food) restaurant network. Chinese physicians, travel agencies, real-estate agents, hairdressers, entertainers and missionaries colored the palette of Chinese migration conceived in terms of entrepreneurship and the middleman minority model (Nyíri 2006). The development of a social entrepreneurial 
Nagy, Dorottya. "Displaying Diaspora: Chinese Christian Presence in Hungary after 1989.” AHEA: E-journal of the American Hungarian Educators Association, Volume 5 (2012): http://ahea.net/e-journal/volume-5-2012

network also lead to geographical expansion. The "Chinese shop" phenomenon reached even the most remote villages in Hungary, and even when the owner of the shop was not an actual resident in those villages, there was still a sense of direct experience of $\mathrm{CMH}$ through the employees in these shops. CMH continuously responds to urban development discourses within Hungary, calling into question the arguments that $\mathrm{CMH}$ is largely restricted to the locality of Budapest. In the late 1990s, Hungary became the major distribution centre of Chinese import good to CEE and the European Union, which eventually lead to the intersection of Chinese migrant interests, Hungarian interests fueled by Hungary's preparation for EU membership, and economic partnership with China, opening a new chapter in the history of CMH.

Although President Árpád Göncz visited China in 1994 and the favor was returned in 1995, economic and cultural contact between China and Hungary only began to intensify in earnest with the Hungarian Prime Minister's visit to China in 2003, when Chinese presence in Hungary became an essential rhetorical element in political discourse, raising the idea of establishing a Hungarian-Chinese bilingual school in Budapest, which was opened in 2004. At its opening the school had 200 students, $60 \%$ of them Chinese and $40 \%$ primarily Hungarian, but by 2011 there was a slight shift in percentages, so that out of the 239 students enrolled, 109 students were Chinese and other nationalities, and 130 were Hungarian. These numbers do not mean that today there are fewer Chinese children in Hungary, but rather might indicate that not all Chinese parents send their children to this particular school, since the International Christian School of Budapest and Hungarian schools with good educational reputation are also popular among Chinese parents. Flourishing bilateral also relations lead to Hungary becoming the first CEE country to host a branch of the Bank of China, establish a Confucian Institute, offer direct flights between Beijing and Budapest, operate a center for the Huawei telecommunications company, act as the largest trade center with dominantly Chinese companies (Asia Center) and teach traditional Chinese medicine at an accredited University. Hungary is also an attractive economic partner to China due to the fact that Hungary has the largest Chinese population in CEE and since most of the migrants arrived in the nineties they thus have substantial work experience and knowledge about Hungarian society (Szunomár 2011). For example, some of the migrants who arrived to Hungary as Tiananmen activists are now affiliated with government supported businesses in Hungary. The quote below comes from a church member, who is also a former Tiananmen activist:

\footnotetext{
It was during that time that things went very bad with my business. I considered going home. The brothers and sisters were praying for me and my family. I really didn't know what to do.. and then one Monday, I got a phone call from China. It was an uncle of mine and he told me that he heard that they [not clear who] are searching for people who could do business in Hungary. I told him to have them call me. [...] It took me some time to calm down. The pastor helped me a lot. Can you imagine, me working for the Chinese government... God is funny. God is great. When I came to Hungary, I was not a Christian. I thought that I loved my country... I almost died for my country... and here I met Christ and now I try to live as a Christian. [...] I love my country even more. ${ }^{2}$
}

Although CMH continues to be dominantly entrepreneurial, the diversity of SinoHungarian relationships does lead to new degrees of diversification within $\mathrm{CMH}$. The appearance of "second generation" migrants and greater visibility of Chinese students in Hungarian higher education (the Office for Immigration and Nationality counted 836 Chinese students accepted to universities in 2008) increases social diversity as well, since the children of first-generation uneducated or less educated migrants may reach higher social status

\footnotetext{
${ }^{2}$ Unless stated otherwise, the quotes are the author's translation from Mandarin.
} 
Nagy, Dorottya. "Displaying Diaspora: Chinese Christian Presence in Hungary after 1989.” AHEA: E-journal of the American Hungarian Educators Association, Volume 5 (2012): http://ahea.net/e-journal/volume-5-2012

through education than their parents. As one 24-year-old Chinese man put it in perfect Hungarian: "The mere fact that I can speak both Chinese and Hungarian perfectly and studied English as well puts me in the luxurious position of being able to reject certain jobs I do not find interesting. Many of my Hungarian friends do not have such choices." High mobility and diversity both in migration and settlement practices continue to characterize $\mathrm{CMH}$, and act as the major means of forming, maintaining and shaping both global transnational networks and local communities. Chinese migrants remain a significant entity to be reckoned with in migration studies through which Hungary's transformation into a country of immigration and an arena of transnational migrations can be studied.

Chinese migrants create multiple types of communities and/or community-like associations (business, language, culture, charity, religious and so on) which effectively contribute to networking and create a sense of belonging, and therefore it would be inappropriate to essentialize $\mathrm{CMH}$ as "the" Chinese community or "the Chinese diaspora" (Ma and Cartier 2003) in Hungary despite the fact that diaspora discourses are crucial for formation of a given community. Local Christian communities are formed mainly through "Chinese" missionaries (another type of migrant) arriving to Hungary from multiple localities, and the formation of such communities places $\mathrm{CMH}$ not only within the broader context of Chinese globalization but also into the imagined body called Chinese Christianity and its empirical form, the globalization of Chinese Christianity (Nagy 2010). The emergence of the image of Chinese Christianity and the globalization of Chinese Christianity as conceptual frameworks date back to identity formation dynamics within the Overseas Chinese communities in the U.S., where the identity label 'Chinese' remains a constant challenge for settling the issue of what constitutes "Chineseness". Therefore, the appearance of the first Chinese migrants' churches in the North American migratory context in the second half of the nineteenth century should be taken as an important milestone in the globalization of Chinese Christianity. Chinese migrants negotiated identity in the reality of nation states and its understanding of culture closely defined through the Christian label. With time, Chinese Christian communities in North America and the United Kingdom founded and after the birth of PRC refounded countless missionary organizations to realize their vision of Christianizing their fellow Chinese migrants and the whole Chinese community, first in North America, and later within the global Chinese overseas community as well. These Chinese missionary organizations, founded on non-Chinese language territory, were later joined by Chinese missionary organizations emerging on Chinese language territories such as Taiwan and Hong Kong. A significant number of missionary organizations had a clear historical link to forced or voluntary emigration from PRC around 1949.

As the third millennium begins, Chinese migrants are targeted for evangelization or missionization to Christianity worldwide through the formation of global networks and their parallels in Chinese missionary organizations due to diverse migratory processes and the subsequent encounters of Christians and Chinese people. Therefore, Chinese churches, Christian fellowships and communities as well as Chinese missionary organizations are influential actors of what is called the globalization of Chinese migration and Christianity. Christianity labeled as 'Chinese' Christianity creates the sense of a powerful community moving on the global stage, a community which exercises power at different levels, a power to which others react either positively or negatively. It is within this framework that CMH encounters the Christian message and, consequently, Chinese migrants' churches and Christian communities are formed.

In the early nineties, the establishment of the first Chinese Christian church in Hungary with strong international and transnational ties seemed to change the dominant pattern of Chinese evangelizing Chinese, but this exceptional period did not last long and the 
Nagy, Dorottya. "Displaying Diaspora: Chinese Christian Presence in Hungary after 1989.” AHEA: E-journal of the American Hungarian Educators Association, Volume 5 (2012): http://ahea.net/e-journal/volume-5-2012

strength of Chinese Christianity discourses had become visible in Hungary as well as abroad. The structuring of this new community was carried out by a Korean Methodist missionary seeking to form a community deeply rooted in the socio-political and cultural setting an conditioned by $\mathrm{CMH}$. By the time it was officially registered with the government in 1992, the Chinese Christian Church of Budapest counted more than 100 members. Even the name of the Church indicated a willingness to become, as one of the informants put it, "a beacon of light, the salt of the city", acting as a beacon for fellow non-Christian PRC migrants and also as a witnessing community in Budapest. For the core community, which was dominantly formed by migrants who had already encountered Christianity in the PRC, the Chinese element was crucial in terms of language use, with Mandarin becoming the lingua franca of practicing faith, but not the primary unit of identification. Instead, identity development was informed by the Christian metanarrative of one human family and the sense of being conditioned through migration, celebrating diversity, internationality, transdenominationality, and the idea of realized world Christianity. Within the formal settings of using a rented Hungarian church building and having a Korean pastor, the issue of Chineseness was more of a language issue rather than an ethnic narrative. The actual social-economic situation, migranthood, and the "desperate longing" for a better life, which migrants claimed to have found through faith in Jesus Christ, were more in the center of attention than narratives of ethnic or national belonging. Through the diaconal department of the community, the community started to address the question of the apparent poverty of many Chinese in Budapest, and eventually, non-Chinese leadership and relatively close contact with a Hungarian-speaking community created a sense of celebrating multiculturality and lead to confessions such as the following excerpt:

God has talked to me through pastor K. He is a Korean, you know, he could not even talk to me but showed me the film about Jesus. I was moved. I had to come all the way from China to Hungary so that a Korean pastor could show me the film about Jesus in my language. He also helped me with my documents. He spent hours and hours with me trying to help me. And then a Hungarian pastor baptized me. God is great! For him it doesn't matter if you are Chinese or Korean or Hungarian, He wants you, He loves you. I pray that my family will know Him as well.

As soon as the Chinese presence in Hungary entered the collective consciousness of Chinese missionary organizations in the U.S., the UK, Canada, Taiwan and Hong Kong, the multicultural ideal reverted to negotiating Chineseness through Christian identity. Chinese missionary organizations formed several smaller charismatic or evangelical communities that split further into groups of 20 to 200 members through negotiations of missionary influence and personal power-relationships. Besides the presence of Chinese Christian migrants, the first period of community formation was characterized by conversion-stories from the community members and stories about revitalized Christian identity. One of the first missionary organizations in Hungary was the UK-based Chinese Overseas Christian Mission (COCM) operating with the motto "Reaching the Chinese to Reach Europe". COCM had established churches in most European countries, seeking ecumenical cooperation amongst all Chinese churches in Europe and thus offering Chinese migrants an alternative means of networking where social, cultural and spiritual "capital" can be shared. Chinese Christian communities and fellowships in Hungary create a sense of close belonging, where the language of sisterhood and brotherhood creates the feeling of belonging to one big family (which perfectly resonates with the PRC's political language of creating one big Chinese family), while a sense of moral obligation and accountability is created by frequent and intensive meetings and shared and collectively confessed faith. This makes the community the most influential organization in the life of Christian migrants, since Chinese Christian 
communities enable migrants to create new social networks and social support systems in a foreign, unfamiliar and, from time to time, even hostile environment. Christian communities shape the everyday life and history of the wider group of Chinese migrants, and also play an important role in shaping the image of Chinese migrants among the "local" population.

Although missionization often occurs through missionaries who often have little or no working knowledge about the "host" societies, as in the example of the Korean pastor above, Chinese migrants tend to show a high eagerness to contextualize their faith, and Bible studies, prayer meetings, women's and youth groups are excellent occasions for their purposes.

Missionaries do influence theological thinking, but the ultimate faith paradigm is constructed in pragmatic and functional terms. When Chinese migrants read the Bible, they ask questions such as how is it relevant to the present situation, and what kind of implications does it have for one's life and work in the given circumstances. Answering these questions on the local level means acting as a "missionary" not just towards other fellow Chinese citizens in Hungary, but also acting as a missionary towards Hungarians or other ethnic groups in the country. For instance, one of the four communities in Budapest is engaged in missionary work among the Roma people in Hungary, which is an exceptional example of how two differently marginalized groups in the same society engage in interaction through missionary activities, while contacts with Hungarian Christians are sporadic or non-existent. One of the communities rented a Reformed Church in Budapest, which resulted in the establishment of mutual contact between the Chinese and Hungarian communities. However, since the two communities do not speak each other's language, communication problems discouraged maintaining contact, and when the second generation started to become visible, these contacts were not re-established due to major differences in their respective spiritualities. In this sense, Chinese Christian communities in Hungary are one of the many parallel Christian dimensions on the palette of Christian communities in post-1989 Hungary.

Missionaries, most of whom have migration histories on the personal level and have become migrants for the sake of evangelizing fellow Chinese people, address the issue of contextualization through the question of how to be a good Chinese Christian, which generally translates to PRC migrants as how to be a devoted PRC citizen and a devoted Christian, since patriotism and Christian devotion (women Zhongguo ren 'we PRC people' and women Jidutu 'we Christians') go hand in hand for PRC migrants. In spite of the fact that interactions between non-PRC Chinese missionaries and PRC migrants are not always smooth, the aspiration of becoming a good Christian means becoming an even better Chinese person, and thus a witness to the wider world. Basically outside China for Chinese Christians the concept of "wherever God calls us to go" creates a sense of unity. Contrary to the classical sociological arguments that religious belonging contributes to assimilation and social integration into the "host" society (Gordon 1964), fieldwork shows that, while Christian communities of Chinese migrants in Hungary choose to interact on several levels with the "host" societies, their primary aim is never assimilation or socio-cultural integration but rather becoming a witness of Jesus Christ in one's own environment, empowered by belonging to an imagined global community of Chinese Christians.

Since missionaries are aware of how migrants' lives are conditioned by migration, they approach and contextualize the question of Chineseness through diaspora rhetoric. Similarly to Korean missionaries, they conceptualize diaspora through the question of a nation's role and importance in God's plan for the Earth, and in this approach, Chinese people have a distinguished task to fulfill in the present generation. Such contextualizations as well as conceptualizations of diaspora within the emerging field of diaspora missiology (Wan 2011) call for deeper theological elaboration, and as such cannot be included within the scope of this paper. Instead, discussion remains on the level of participant observation and tries to 
Nagy, Dorottya. "Displaying Diaspora: Chinese Christian Presence in Hungary after 1989.” AHEA: E-journal of the American Hungarian Educators Association, Volume 5 (2012): http://ahea.net/e-journal/volume-5-2012

formulate the contours of diaspora discourses within Chinese Christian communities in Hungary. The Chinese term for diaspora (liusan) is hardly ever used, but sermons, songs, testimonies, and group discussions frequently use words and phrases such as sending, guidance, travelling, pilgrims, being in a foreign land, being scattered, which shows a tendency to perceive the present state of migranthood as God's plan to scatter Chinese people all over the world so that "the Good News of Jesus Christ would be heard and people may turn to God" and the "Good News could be brought back to China" through the experience of migration. The quote below illustrates how migration understood as dispersion contributes to identity formation for many Christian Chinese:

\begin{abstract}
Many Chinese who are not Christians look at Jesus as if he were a Westerner. They think that if you believe in Jesus, you sell out your country. Jesus is not a Westerner. I try to tell them that by meeting Jesus, I became a more faithful Chinese. I know that if everybody in China would become a Christian, there would be no poverty, there would not be corruption. But they don't understand. A long time ago I thought the same, but now I know that God wants the best for us Chinese people (Nagy 2009: 130).
\end{abstract}

Following the arguments of Wang Gongwu, Gregor Benton and Hong Liu call for caution when looking at Chinese migration in terms of diaspora since it homogenizes Chinese migration and may easily nurture the image of a "new yellow peril". For instance, some believe that China is behind the whole of Chinese migration, sending out people and establishing a worldwide network like some enormous octopus spreading its tentacles across the globe. When one is using an out-of-context word like diaspora, it is bound to create such false assumptions about China and Chinese migration (Benton and Liu 2004: 50-51). Therefore, using the term cautiously on an academic level is justified and necessary, but at the same time, the case of Chinese Christian communities in Hungary creates a situation where understanding the use of diaspora rhetoric is crucial for understanding how identities are formed and shaped. Missionary discourse does not deny the existence of diversity of Chinese Christian communities, but rather uses the image of diaspora (God's purpose to scatter Chinese all around the world) to strengthen the metanarrative of Chineseness, which is

not a natural outcome of a genealogical tree, but a continuous struggle along multiple historical
and social nodes and negotiating the inescapable tension between secure definitions and being
conscious of the oppressive notions that such definitions rest upon. It is still partial and
forming, providing a redemptive psychic locus and a step towards solidarity, towards
belonging, and invests the idea of an original "Chineseness" with authenticity, an enhanced
aura clearly desired by many of its diasporic subjects and Others. (Wong 2003: 6)

If we understand migration as diaspora, such a conceptualization of Chineseness fits perfectly with the PRC's new Chinese migrant policies of "one China" and "Chinese all over the world being one big family" and suggests that Christianity is the ultimate form of patriotism. It enables Chinese Christian migrants in Hungary to become agents of modernity as envisioned by the PRC, and the idea God being the agent of dispersion also legitimates both the open-ended character of migration and the high mobility of migrants. In this context, the question raised by Chinese Christians is no longer "where do I come from" but "where am I supposed to be," as illustrated by the follow quote from another Chinese Christian, an excerpt taken from a long Bible study in 2005:

My home is God's kingdom [said the Taiwan-born US citizen working as a missionary in Hungary], it's not China, it's not America, but God's kingdom. That is where I work, that is my home. We lived in Canada, we lived in Beijing, in San Diego, and then God called us to move on. We all live first of foremost in God's kingdom. 
Nagy, Dorottya. "Displaying Diaspora: Chinese Christian Presence in Hungary after 1989.” AHEA: E-journal of the American Hungarian Educators Association, Volume 5 (2012): http://ahea.net/e-journal/volume-5-2012

\begin{abstract}
You are right [added a PRC migrant who came to Hungary in 1991]. We live in God's kingdom, but we were born in China. This is not a coincidence. I believe that God brought me to Hungary and maybe one day He will say: you must go to another country. The most important thing is to do what He wants us to do. I agree, but how do you know God's will for sure [says another PRC migrant who arrived in Hungary in 2000]. My wife and I have been praying for a while to move onward to Canada. We have relatives there who say that God told them to invite us there. We don't know. We are struggling a lot.
\end{abstract}

The idea of constructing religious identity in migranthood through the concept of diaspora suggests that the "host" country's policies of migrant assimilation or integration has little to no appeal to Chinese Christian migrants. Instead, integration is sought more in the imagined worldwide Chinese Christianity, where Hungary becomes a mission field in the first place and in the case of young Chinese Christians (those already born in Hungary) a home country which needs to be re-minded of what "real" Christianity is. A sixteen years old girl, born in Hungary and fluent in Hungarian (yet attending the International Christian School in Budapest) said: "I have many Hungarian friends. Most of them are baptized but they never go to church and they don't want to speak about Jesus Christ." To the question about her future she answered: "I would like to become a missionary. Maybe God wants me to serve Him here in Hungary."

This paper discussed the phenomenon of $\mathrm{CMH}$, focusing on Chinese Christian communities in Hungary and calling attention to the fact that $\mathrm{CMH}$ is not only about the diversity of PRC migrants but also about non-PRC migrants who identify as Chinese. By examining diaspora discourses and the case of Chinese Christian presence in post-1989 Hungary, this article also aims to contribute to a shift in diaspora studies inasmuch as it proposes, in light of the arguments presented above, to talk about "diaspora Chinese" instead of "Chinese diaspora(s)".

\title{
Works Cited
}

Barabantseva, Elena. 2005. "Trans-Nationalising Chineseness: Overseas Chinese Policies of the PRC's Central Government”, ASIEN 96: 7-28.

Benton, Gregor and Liu Hong. 2004. Diasporic Ventures: The Life and Work of Wang Gongwu. London, NY: Routledge.

Cohen, Robin. 1998. Global Diasporas: An Introduction. Seattle: University of Washington Press.

Gordon, Milton M. 1964. Assimilation in American Life: The Role of Race, Religion and National Origins. USA: Oxford University Press.

Irimiás Anna. 2008. "Budapesten élő kínai közösség (Chinese Communities Living in Budapest)." Földrajzi értesitő. LVII. 1-2: 469-484.

Ma, Laurence J. and Carolyn Cartier (eds.) 2003. The Chinese Diaspora: Space, Place, Mobility and Identity. Lanham: Rowman \& Littlefield.

Mészáros, Klára. 1998. “Kínaiak Európában. Kínai migráció az Eu-országokban.” Korunk. 3.8:45-51.

Mette, Thunø. 2001. "Reaching Out and Incorporating Chinese Overseas: The TransTerritorial Scope of the PRC by the End of the Twentieth Century." The China Quarterly 168: 910-928. 
Nagy, Dorottya. "Displaying Diaspora: Chinese Christian Presence in Hungary after 1989.” AHEA: E-journal of the American Hungarian Educators Association, Volume 5 (2012): http://ahea.net/e-journal/volume-5-2012

Nagy, Dorottya. 2009. Migration and Theology: The Case of Chinese Christian Communities in Hungary and Romania in the Globalization-Context. Zoetermeer: Boekencentrum. . 2010. "Feuerdrachen: Chinesische Gemeinschaften in Mittel- und Osteuropa," China Heute 29.4: 235-245.

Nyíri, Pál. 1997. "Organisation and Integration in a New Overseas Chinese CommunityHungary 1989-1997." In Endre Sík, Maryellen Fullerton and Judit Tóth (eds.) From Improvisation towards Awareness? Contemporary Migration Politics in Hungary. Budapest: Institute for Political Sciences, Hungarian Academy of Sciences. 50-84. . 1999. "Chinese Organizations in Hungary, 1989-1996: A Case Study in PRC-

Oriented Community Politics Overseas.” In Frank N. Pieke and Hein Mallee (eds.) Internal and International Migration: Chinese Perspectives. Surrey. Curzon Press. 251-279.

. 2001. "Expatriating Is Patriotic? The Discourse on "New Migrants" in the People's Republic of China and Identity Construction among Recent Migrants from the PRC." Journal of Ethnic and Migration Studies 27.4: 635-653. . 2003. "Xenophobia in Hungary: A Regional Comparison," Working Paper Series.

Budapest: Central European University: Center for Policy Studies. . 2005. "Global Modernizers or Local Subalterns? Parallel Perceptions of Chinese Transnationals in Hungary." Journal of Ethnic and Migration Studies 31.4: 659-674. . 2006. "Transnationalism and the Middleman Minority Model: Chinese Entrepreneurs in Hungary." In William C. Kirby, Mechthild Leutner, Klaus Mühlhahn. Global Conjectures: China in Transnational Perspective. Berlin. LIT Verlag. 73-91. . 2010. "Kínai migránsok Magyarországon: Mai tudásunk és aktuális kérdések (Chinese Migrants in Hungary and Current Issues).” In Hárs Ágnes, Tóth Judit (eds.) Változó migráció, változó környezet. Budapest. MTA Etnikai-nemzeti Kisebbségkutató Intézet. 147-171.

Okólski, Marek and Grabowska-Lusińska. 2009. "Introduction.” In Dušan Drbohlav, Ágnes Hárs, Izabela Grabowska-Lusińska (eds.) Experiencing Immigration: Comparative Analysis of the Czech Republic, Hungary and Poland. IDEA Working Papers: 14. 515.

Polonyi, Péter. 2008. “A magyarországi kínai kolónia problémáiról (On Problems of the Hungarian Chinese Colony)." In András Inotai and Otto Juhász. Kína: Realitás és esély. Tanulmányok Magyarország Kína stratégiájának megalapozásához. Budapest: Magyar Tudományos Akadémia, Miniszterelnöki Hivatal. 328-346.

Sík, Endre. 1999. "The Developments of Open-Air Markets in East-Central Europe." International Journal of Urban and Regional Research. 23: 697-714.

Szunomár, Ágnes. 2011. "The Roots of Chinese-Central European Relations: The Case of Hungary.", Hungary's EU Presidency Series. 34 (23 September).

Vámos, Péter. 2006. "Sino-Hungarian Relations and the 1956 Revolution." Working Paper. Woodrow Wilson International Center for Scholars in Washington, D.C. The Cold War International History Project. 54. http://www.coldwar.hu/html/en/starting\%20page/WP54_Final2.pdf 12/07/2009.

Vertovec, Steven and Robin Cohen (eds.) 1999. Migration, Diasporas and Transnationalism. Aldershot: Edward Elgar.

Wan. Enoch. (ed.) 2011. Diaspora Missiology: Theory, Methodology and Practice. Portland: Institute of Diaspora Studies.

Wong, Loong. 2003. "Belonging and Diaspora: The Chinese and the Internet," First Monday 8. 